\title{
Effects of Nitrogen Addition on Leaf Decomposition of Single-Species and Litter Mixture in Pinus tabulaeformis Forests
}

\author{
Jinsong Wang ${ }^{1,2}$, Wensheng Bu ${ }^{3}$, Bo Zhao ${ }^{1}$, Xiuhai Zhao ${ }^{1, *}$, Chunyu Zhang ${ }^{1}$, Juan Fan ${ }^{1}$ and \\ Klaus V. Gadow 4,5
}

Received: 8 June 2015; Accepted: 12 November 2015; Published: 4 December 2015

Academic Editors: Reynaldo Santana and Eric J. Jokela

1 Key Laboratory for Forest Resources \& Ecosystem Processes, Beijing Forestry University, Beijing 100083, China; wangjinsong@caf.ac.cn (J.W.); job0824@163.com (B.Z.); zcy_0520@163.com (C.Z.); magnolia-fanjuan@163.com (J.F.)

2 Research Institute of Forest Ecology, Environment and Protection, Chinese Academy of Forestry, Beijing 100091, China

3 College of Forestry, Jiangxi Agricultural University, Nanchang 330045, China; bws2007@163.com

4 Department of Forestry and Wood Technology, University of Stellenbosch, Stellenbosch, South Africa

5 Faculty of Forestry and Forest Ecology, Georg-August-University Göttingen, Büsgenweg 5, Göttingen D-37077, Germany; kgadow@gwdg.de

* Correspondence: zhaoxh@bjfu.edu.cn; Tel.: +86-010-6233-6189; Fax: +86-010-6233-8197

\begin{abstract}
The litter decomposition process is closely correlated with nutrient cycling and the maintenance of soil fertility in the forest ecosystem. In particular, the intense environmental concern about atmospheric nitrogen $(\mathrm{N})$ deposition requires a better understanding of its influence on the litter decomposition process. This study examines the responses of single-species litter and litter mixture decomposition processes to $\mathrm{N}$ addition in Chinese pine (Pinus tabulaeformis Carr.) ecosystems. Chinese pine litter, Mongolian oak (Quercus mongolica Fisch. ex Ledeb.) litter, and a pine-oak mixture were selected from a plantation and a natural forest of Chinese pine. Four $\mathrm{N}$ addition treatments, i.e., control (N0: $0 \mathrm{~kg} \mathrm{~N} \mathrm{ha}^{-1}$. year $^{-1}$ ), low-N (N1: $50 \mathrm{~kg} \mathrm{~N} \mathrm{ha}^{-1}$. year $^{-1}$ ), medium-N (N2: $100 \mathrm{~kg} \mathrm{~N} \mathrm{ha}^{-1} \cdot$ year $\left.^{-1}\right)$, and high-N (N3: $150 \mathrm{~kg} \mathrm{~N} \mathrm{ha}^{-1} \cdot$ year $^{-1}$ ), were applied starting May 2010. In the plantation, $\mathrm{N}$ addition significantly stimulated the decomposition of the Chinese pine litter. In the natural forest, $\mathrm{N}$ addition had variable effects on the decomposition of single-species litter and the litter mixture. A stimulatory effect of the high-N treatment on the Chinese pine litter decomposition could be attributed to a decrease in the substrate C:N ratio. However, an opposite effect was found for the Mongolian oak litter decomposition. The stimulating effect of $\mathrm{N}$ addition on the Chinese pine litter may offset the suppressive effect on the Mongolian oak litter, resulting in a neutral effect on the litter mixture. These results suggest that the different responses in decomposition of single-species litter and the litter mixture to $\mathrm{N}$ addition are mainly attributed to litter chemical composition. Further investigations are required to characterize the effect of long-term high-level $\mathrm{N}$ addition on the litter decomposition as $\mathrm{N}$ deposition is likely to increase rapidly in the region where this study was conducted.
\end{abstract}

Keywords: litter quality; nutrient enrichment; single-species litter; litter mixture; Chinese pine forests

\section{Introduction}

The combustion of fossil fuels, nitrogen $(\mathrm{N})$ fertilizer use, and other human activities have doubled the amount of terrestrial $\mathrm{N}$ inputs on the global scale [1] and substantially altered the $\mathrm{N}$ 
cycle [2]. Global production of reactive $\mathrm{N}$ increased from $\sim 15 \mathrm{Tg} \mathrm{N} \cdot$ year $^{-1}$ in 1860 to $187 \mathrm{Tg} \mathrm{N} \cdot$ year $^{-1}$ in 2005 and is expected to increase by between $50 \%$ and $100 \%$ by 2030 relative to 2000 [3]. China hasbecome the third largest area of atmospheric $\mathrm{N}$ deposition following the northeastern United States and Europe [4]. Over the last decades production of reactive $\mathrm{N}$ in China increased from $14 \mathrm{Tg} \mathrm{N} \cdot$ year $^{-1}$ in 1961 to $68 \mathrm{Tg} \mathrm{N} \cdot$ year $^{-1}$ in 2000 and is predicted to reach $105 \mathrm{Tg} \mathrm{N} \cdot$ year $^{-1}$ in 2030 as a result of human activities [5].

Atmospheric $\mathrm{N}$ deposition has been a major source of anthropogenic $\mathrm{N}$ in various ecosystems. At present, elevated $\mathrm{N}$ deposition is becoming a prevailing problem affecting nearly every aspect of the function and composition of forest ecosystems [6]. Litter decomposition is an important process in the forest ecosystem. The litter decomposition process and its rate are vital in regulating the formation of soil organic matter and the release of nutrients for plants and microorganisms [7]. Moreover, the amount of carbon $(\mathrm{C})$ returned to the atmosphere as carbon dioxide $\left(\mathrm{CO}_{2}\right)$ from decomposed litter may account for $10 \%-30 \%$ of total soil $\mathrm{CO}_{2}$ flux, which is important for forest $\mathrm{C}$ budgets [8]. In the context of increasing $\mathrm{N}$ deposition, there is an interest in understanding the effects of $\mathrm{N}$ inputs on the litter decomposition process, particularly with respect to its potential effects on C and $\mathrm{N}$ cycles [9].

Litter decomposition is generally regulated by a number of biotic (e.g., litter quality and decomposing organisms) and abiotic factors (e.g., macro- and micro-climate, soil properties) [10]. This process is also thought to be constrained by soil $\mathrm{N}$ availability [11]. $\mathrm{N}$ addition accelerates the soil $\mathrm{N}$ mineralization rate, and is likely to increase soil $\mathrm{N}$ availability [12]. However, results concerning the effect of $\mathrm{N}$ addition on the litter decomposition rate are variable. Several studies have demonstrated significantly lower decay rates in response to $\mathrm{N}$ addition [13-15], while others have shown either no significant change [16,17] or stimulation of decay rates [18,19]. A meta-analysis concluded that the response of litter decomposition to $\mathrm{N}$ addition is tied to $\mathrm{N}$ addition rates, site-specific ambient $\mathrm{N}$-deposition level, experimental design (e.g., fertilizer type, experiment duration, litterbag mesh size), and litter quality [20].

There is growing evidence that considerable variations in the litter decomposition rate exist between single-species litters and litter mixtures [21-23]. In a forest ecosystem, the decay rates and nutrient dynamics of a litter mixture might be substantially different from those of individual species, hence the occurrence of a synergistic or antagonistic effect, which depends on the chemical interactions of individual litter types in the litter mixture [24]. The review by Gartner and Cardon [25] concluded that the synergistic and antagonistic effects were observed in $50 \%$ and $20 \%$ of all litter mixtures, respectively. It has been reported that nutrients released from rapidly decaying litter could accelerate the decomposition of the other litter in the litter mixture, leading to a synergistic effect [26]. Conversely, the release of recalcitrant compounds during the decay of one litter acting as inhibitors of the decomposition of the mixture would induce an antagonistic effect [27].

Previous research on single-species litter decomposition reported strong correlations between its decomposition rate and litter chemical composition, and especially initial $\mathrm{N}$ concentration and the ratios C:N, lignin:N [28,29]. Chinese pine (Pinus tabulaeformis) is a geographically widely distributed native tree species in Northern China, occurring at latitudes between $31^{\circ} 13^{\prime} \mathrm{N}$ and $43^{\circ} 33^{\prime} \mathrm{N}$ and at longitudes between $103^{\circ} 20^{\prime} \mathrm{E}$ and $124^{\circ} 45^{\prime} \mathrm{E}$ [30], and covering an estimated total area of $228.1 \times 10^{4}$ ha [31]. In Northern China, Chinese pine grows in mixed stands with Mongolian oak (Quercus mongolica). Chinese pine and Mongolian oak show distinct differences in the litter chemical composition, and these differences may drive interactions in the litter mixture. Despite many studies dealing with the process of litter decomposition and evaluating the differences between single-species litter and litter mixtures [32-34], studies investigating specific responses of single-species litter and litter mixture decomposition to $\mathrm{N}$ addition are still scarce [35-37] and the underlying mechanisms are not yet well understood.

This study is based on an in situ $\mathrm{N}$ addition experiment aimed at assessing the effect of $\mathrm{N}$ addition on the decomposition of the Chinese pine litter in a plantation. We also examined the responses in the decomposition of single-species litter (Chinese pine, Mongolian oak) and a 
pine-oak mixture to $\mathrm{N}$ addition in a natural forest of Chinese pine. Accordingly, we hypothesized that: (1) all litter types decompose faster in the natural forest than the Chinese pine litter in the plantation; (2) Chinese pine litter decomposes more slowly alone than in a mixture with Mongolian oak litter with a relatively higher concentration of nutrients[37]; and (3) $\mathrm{N}$ addition accelerates the decomposition of single-species litter and litter mixture in both plantations and natural forests.

\section{Materials and Methods}

\subsection{Study Area}

The litter decomposition experiment was conducted at the Taiyue Mountain Ecosystem Research Station located in Shanxi Province, in northern China $\left(36^{\circ} 18^{\prime} \mathrm{N}, 111^{\circ} 45^{\prime} \mathrm{E}, 1560 \mathrm{~m}\right.$ a.s.l). The region has a warm-temperate semi-arid continental monsoon-affected climate. Mean annual precipitation is $548 \mathrm{~mm}$ with a mean relative humidity of $65 \%$. The distribution of precipitation over the year is relatively uneven. The wet season lasts from July to September and accounts for more than $60 \%$ of the annual precipitation. The mean annual temperature is $9.9^{\circ} \mathrm{C}$. The highest monthly average temperature of $22.4{ }^{\circ} \mathrm{C}$ is observed in July while the lowest monthly average temperature of $-4.6{ }^{\circ} \mathrm{C}$ occurs in January. The soil is a furnace black forest soil.

The vegetation cover at the study site represents a warm-temperate, deciduous, broad-leaved forest zone. The forest canopy mainly comprises Pinus tabulaeformis, Quercus mongolica, and Populus davidiana. The understory consists mainly of Ostryopsis davidiana Decaisne, Lespedeza bicolor Turcz., Hippophae rhamnoides L., Corylus mandshurica Maxim., Swida bretchneideri, and Rosa xanthina Lindl. The mean height of the understory is $2.2 \mathrm{~m}$ with a mean diameter at breast height (DBH) of $2.0 \mathrm{~cm}$. Common herbs are Carex tristachya and various species of the family Cyperaceae [38].

\subsection{Experimental Design}

Twelve $20 \times 20 \mathrm{~m}$ plots were set up in a plantation and in a natural forest of Chinese pine in May 2009. The plantation and natural forest are located about $5 \mathrm{~km}$ apart. The plantation was managed by selective logging in the 1980s while the natural forest was protected from human impacts after the establishment of "a new China" in 1949. The litter layer in the natural forest is thicker than that in the plantation. All the plots were laid out randomly and each plot is surrounded by a $10 \mathrm{~m}$ wide buffer strip. Species of all live and dead trees with diameter at breast height (DBH) greater than $1 \mathrm{~cm}$ were tagged and identified in each plot. The $\mathrm{DBH}$, tree height, and crown dimension of each tree were measured and recorded. The characteristics of each plot are shown in Table 1.

Table 1. Stand characteristics of four $\mathrm{N}$ addition treatment plots in the plantation and natural forests of Chinese pine.

\begin{tabular}{cccccccc}
\hline $\begin{array}{c}\text { Forest } \\
\text { Type }\end{array}$ & $\begin{array}{c}\text { Nitrogen } \\
\text { Treatment }\end{array}$ & $\begin{array}{c}\text { Forest } \\
\text { Age } \\
\text { (year) }\end{array}$ & $\begin{array}{c}\text { Density } \\
\text { (Trees per } \\
\text { Hectare) }\end{array}$ & $\begin{array}{c}\text { Mean Diameter } \\
\text { at Breast } \\
\text { Height } \mathbf{( c m )}\end{array}$ & $\begin{array}{c}\text { Mean Tree } \\
\text { Height } \\
\text { (m) }\end{array}$ & $\begin{array}{c}\text { Slope } \\
\text { (Degree) }\end{array}$ & $\begin{array}{c}\text { Elevation } \\
\text { (m) }\end{array}$ \\
\hline \multirow{5}{*}{ Plantation } & Control & 60 & 858 & 17.8 & 13.1 & 19 & 1589 \\
& Low-N & 60 & 725 & 21.2 & 13.8 & 15 & 1589 \\
& Medium-N & 60 & 692 & 20.2 & 11.6 & 19 & 1589 \\
& High-N & 60 & 658 & 20.5 & 12.4 & 18 & 1589 \\
\hline \multirow{2}{*}{ Natural } & Control & 75 & 1267 & 23.9 & 17.7 & 24 & 1680 \\
forest & Low-N & 75 & 1567 & 20.6 & 17.8 & 21 & 1680 \\
& Medium-N & 75 & 1208 & 23.5 & 17.4 & 25 & 1680 \\
& High-N & 75 & 1225 & 23.4 & 19.0 & 23 & 1680 \\
\hline
\end{tabular}

Twenty soil samples were collected in each plot from the top soil $(0-20 \mathrm{~cm})$ in August 2009 . All samples in each plot were combined to one sample and sieved using a $2 \mathrm{~mm}$ mesh net to remove coarse fragments and then air-dried to analyze $\mathrm{pH}$ and nutrient contents. Soil $\mathrm{pH}$ value was 
measured using a glass electrode and a 1:2 soil-to-water ratio. Total $\mathrm{N}$ was analyzed using Kjeldahl's digestion with a salicylic acid modification [39], while available phosphorus $(\mathrm{P})$ and potassium (K) were analyzed using the $\mathrm{NaOH}$ method [40]. Soil organic carbon was measured following the method described by Kalembasa and Jenkinson [41]. The soil properties are presented in Table 2.

Table 2. Mineral soil properties $(0-20 \mathrm{~cm})$ of four $\mathrm{N}$ addition treatment plots in the plantation and natural forests of Chinese pine (Mean $\pm \mathrm{SE}, n=3$ ).

\begin{tabular}{ccccccc}
\hline Forest Type & $\begin{array}{c}\text { Nitrogen } \\
\text { Treatment }\end{array}$ & $\begin{array}{c}\text { Soil Bulk } \\
\text { Density } \\
\left(\mathbf{g} / \mathbf{c m}^{3}\right)\end{array}$ & Soil $\mathbf{~ p H}$ & $\begin{array}{c}\text { Total } \\
\text { Nitrogen(g/kg) }\end{array}$ & $\begin{array}{c}\text { Soil Organic } \\
\text { Carbon } \mathbf{( g / k g})\end{array}$ & C/N Ratio \\
\hline \multirow{3}{*}{ Plantation } & Control & $1.3 \pm 0.1 \mathrm{a}$ & $7.4 \pm 0.2 \mathrm{a}$ & $1.0 \pm 0.1 \mathrm{a}$ & $22.9 \pm 3.7 \mathrm{a}$ & $22.5 \pm 0.6 \mathrm{a}$ \\
& Low-N & $1.2 \pm 0.1 \mathrm{a}$ & $7.5 \pm 0.1 \mathrm{a}$ & $1.0 \pm 0.1 \mathrm{a}$ & $22.0 \pm 3.4 \mathrm{a}$ & $22.5 \pm 0.4 \mathrm{a}$ \\
& Medium-N & $1.3 \pm 0.1 \mathrm{a}$ & $7.7 \pm 0.2 \mathrm{a}$ & $1.0 \pm 0.1 \mathrm{a}$ & $22.4 \pm 3.2 \mathrm{a}$ & $22.6 \pm 0.5 \mathrm{a}$ \\
& High-N & $1.3 \pm 0.1 \mathrm{a}$ & $7.7 \pm 0.1 \mathrm{a}$ & $1.0 \pm 0.1 \mathrm{a}$ & $23.4 \pm 3.8 \mathrm{a}$ & $22.7 \pm 0.5 \mathrm{a}$ \\
\hline \multirow{3}{*}{ Natural } & Control & $0.9 \pm 0.0 \mathrm{~b}$ & $7.1 \pm 0.3 \mathrm{~b}$ & $2.1 \pm 0.3 \mathrm{~b}$ & $45.3 \pm 5.9 \mathrm{~b}$ & $22.1 \pm 1.1 \mathrm{a}$ \\
& Low-N & $1.0 \pm 0.0 \mathrm{~b}$ & $7.1 \pm 0.2 \mathrm{~b}$ & $2.0 \pm 0.3 \mathrm{~b}$ & $44.0 \pm 6.1 \mathrm{~b}$ & $21.8 \pm 1.0 \mathrm{a}$ \\
& Medium-N & $1.1 \pm 0.1 \mathrm{~b}$ & $7.2 \pm 0.2 \mathrm{~b}$ & $2.0 \pm 0.3 \mathrm{~b}$ & $44.1 \pm 5.8 \mathrm{~b}$ & $22.0 \pm 1.1 \mathrm{a}$ \\
& High-N & $1.1 \pm 0.1 \mathrm{~b}$ & $7.3 \pm 0.2 \mathrm{~b}$ & $2.1 \pm 0.3 \mathrm{~b}$ & $46.1 \pm 5.7 \mathrm{~b}$ & $22.2 \pm 1.1 \mathrm{a}$ \\
\hline
\end{tabular}

Different letters in the same column represent a significant difference between forest types at the same $\mathrm{N}$ addition treatment. The significance level was set at $\alpha=0.05$.

With a local $\mathrm{N}$ deposition of $21.2 \mathrm{~kg} \mathrm{~N} \mathrm{ha}^{-1} \cdot \mathrm{year}^{-1}$ [38], four treatments (each treatment with three replicates) with $\mathrm{N}$ addition were investigated in the plots: control (N0: $0 \mathrm{~kg} \mathrm{~N} \mathrm{ha}^{-1} \cdot \mathrm{year}^{-1}$ ),

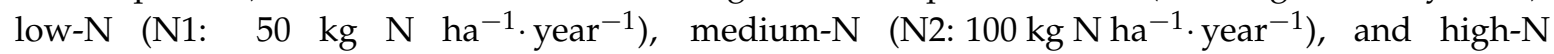
(N3: $150 \mathrm{~kg} \mathrm{~N} \mathrm{ha}{ }^{-1}$.year $\left.{ }^{-1}\right)$. In each plot urea $\left(\mathrm{CO}\left(\mathrm{NH}_{2}\right)_{2}\right)$ was weighed and mixed with 20 liters of water, and sprayed using a portable sprayer onto the forest floor repeatedly at the end of each month from May to October every year. The N0 plot received only 20 liters of water without $\mathrm{N}$ addition. The first $\mathrm{N}$ addition treatment was carried out on 30 May 2010.

\subsection{Leaf Litter Collection, Decomposition, and Chemical Analysis}

In October 2009, leaf litters of Chinese pine were collected in the plantation plots. In the natural forest, Chinese pine and Mongolian oak are the main tree species and litter from both species was collected in those plots. The samples were taken to the laboratory at the Research Station and air-dried for six months in the laboratory. Subsamples of the air-dried samples were oven-dried at $65^{\circ} \mathrm{C}$ to a constant weight to determine the water content of the air-dried samples and then milled to determine the initial litter chemistry (five replications). The total $\mathrm{C}$ and $\mathrm{N}$ concentration were determined with a Sumigraph NC-80 high-sensitivity CN analyzer (Shimadzu, Japan). The concentration of P was determined using a modified Kjeldahl method. Total $\mathrm{K}$, calcium $(\mathrm{Ca})$, and magnesium $(\mathrm{Mg})$ were analyzed by atomic emission spectrometry (ICP Plasma 40, Perkin Elmer, UK) [42].

The litterbag method was used to determine the rate of leaf litter decomposition. The leaves of each species were mixed to obtain a uniform mixture before filling the mesh bags. Litterbags were made of $20 \times 20 \mathrm{~cm}$ polyvinyl. The upper net of each litterbag had a $2 \mathrm{~mm}$ mesh, while the lower one had a $1 \mathrm{~mm}$ mesh. In the plantation, each litterbag was filled with $10.0 \mathrm{~g}$ of single air-dried leaf litter of Chinese pine. In the natural forest, there were three kinds of leaf litters: (1) $10.0 \mathrm{~g}$ of single air-dried Chinese pine litter; (2) $10.0 \mathrm{~g}$ of single air-dried Mongolian oak litter; (3) $10.0 \mathrm{~g}$ of equally mixed Chinese pine (5.0 g) and Mongolian oak (5.0 g) litter. Each kind of leaf litter had 30 litterbags in each plot in the plantation and natural forest. On 29 May 2010, a total of 360 litterbags (Chinese pine) in the plantation and 1080 litterbags (360 Chinese pine, 360 Mongolian oak, 360 litter mixture) in the natural forest were placed on the soil surface in 12 plots.

Three litterbags for each leaf litter were retrieved from each $N$ treatment plot after 3, 6, 12, and 15 months. After each sampling, the litter was removed from litterbags and cleaned of roots and 
adhering soil particles by gentle brushing. Leaf residues were oven-dried at $65{ }^{\circ} \mathrm{C}$ for $48 \mathrm{~h}$ and weighed. The oven-dried litter was milled for chemical analysis in each sampling.

\subsection{Data and Statistical Analysis}

The remaining dry weight of the plant litter in each retrieved litterbag was expressed as a percentage of the initial dry weight of the litter in each litterbag. The first-order exponential decay model [43] of the form $X_{t} / X_{0}=\mathrm{e}^{-k t}$ was fitted to the decomposition data, where $X_{t}$ is the oven-dry weight remaining at time $t, X_{0}$ is the initial oven-dry weight, and $k$ is the annual decomposition rate constant $\left(\right.$ year $^{-1}$ ).

Nutrient release via litter decomposition was expressed as a percentage of initial nutrient content, which was calculated by determining the nutrient content at each sampling divided by the initial nutrient content [44]: $E=\left[\left(M_{t} \times C_{t}\right) /\left(M_{0} \times C_{0}\right)\right] \times 100 \%$ where $E$ is nutrient release (\%); $M_{t}$ is the oven-dry mass at time $t ; C_{t}$ is the nutrient concentration at time $t ; M_{0}$ is the initial oven-dry mass $(\mathrm{g})$; and $C_{0}$ is the initial nutrient concentration $\left(\mathrm{mg} \cdot \mathrm{g}^{-1}\right)$.

Data were checked for deviations from normality and homogeneity of variance before analysis. A two-way analysis of variance (ANOVA) with Fisher's Least significant difference test was performed to test the effects of $\mathrm{N}$ addition treatments and sampling date on the decomposition rate (values of $X_{t} / X_{0}$ ) and the nutrient release [45]. One-way ANOVA was used to test differences in the litter mass remaining, $k$ values, and nutrient release between plantation and the natural forest and among the four $\mathrm{N}$ treatments for each sampling date. The analyses were performed using SPSS 15.0 for Windows (SPSS Inc., Chicago, IL, USA).

\section{Results}

\subsection{Soil Properties and Initial Litter Chemical Composition}

An analysis of the soil properties of the top mineral soil $(0-20 \mathrm{~cm})$ revealed significant differences between the soils in the plantation and in the natural forest for all parameters except the $\mathrm{C} / \mathrm{N}$ ratio (Table 2). Soil total $\mathrm{N}$ and soil organic carbon were significantly higher, while soil bulk density and soil $\mathrm{pH}$ were significantly lower in the natural forest relative to the plantation $(p<0.05)$.

The initial leaf litter chemical composition of the single-species litter and litter mixture was also significantly different (Table 3). Mongolian oak litter had the highest $\mathrm{N}, \mathrm{K}, \mathrm{Ca}, \mathrm{Mg}, \mathrm{N} / \mathrm{P}$ ratio, and the lowest $\mathrm{C}$ and $\mathrm{C} / \mathrm{N}$ ratio compared with the other three leaf litters. Chinese pine in the plantation had the lowest $\mathrm{N}, \mathrm{K}, \mathrm{Ca}, \mathrm{Mg}, \mathrm{N} / \mathrm{P}$ ratio, and the highest $\mathrm{C}$ and $\mathrm{C} / \mathrm{N}$ ratio. These differences were all significant $(p<0.05)$.

Table 3. Initial chemical composition of single-species litter and litter mixture in the plantation and natural forests of Chinese pine (Mean $\pm \mathrm{SE}, n=5$ ).

\begin{tabular}{|c|c|c|c|c|c|c|c|c|c|}
\hline $\begin{array}{l}\text { Forest } \\
\text { Type }\end{array}$ & $\begin{array}{c}\text { Leaf } \\
\text { Litters }\end{array}$ & $\begin{array}{c}\text { Total C } \\
\left(\mathrm{mg} \cdot \mathrm{g}^{-1}\right)\end{array}$ & $\begin{array}{c}\text { Total N } \\
\left(\mathbf{m g} \cdot \mathrm{g}^{-1}\right)\end{array}$ & $\begin{array}{c}\text { Total P } \\
\left(\mathbf{m g} \cdot \mathrm{g}^{-1}\right)\end{array}$ & $\begin{array}{l}\text { Total K } \\
\left(\mathbf{m g} \cdot \mathrm{g}^{-1}\right)\end{array}$ & $\begin{array}{l}\text { Total Ca } \\
\left(\mathrm{mg} \cdot \mathrm{g}^{-1}\right)\end{array}$ & $\begin{array}{l}\text { Total Mg } \\
\left(\mathrm{mg} \cdot \mathrm{g}^{-1}\right)\end{array}$ & C/N Ratio & N/P Ratio \\
\hline Plantation & $\begin{array}{l}\text { Chinese } \\
\text { pine }\end{array}$ & $425.8 \pm 6.5 \mathrm{a}$ & $5.4 \pm 0.3 \mathrm{a}$ & $1.3 \pm 0.6 \mathrm{a}$ & $2.6 \pm 0.1 \mathrm{a}$ & $7.0 \pm 0.3 \mathrm{a}$ & $2.0 \pm 0.1 \mathrm{a}$ & $79.1 \pm 5.5 \mathrm{a}$ & $5.8 \pm 1.8 \mathrm{a}$ \\
\hline \multirow{3}{*}{$\begin{array}{l}\text { Natural } \\
\text { forest }\end{array}$} & $\begin{array}{l}\text { Mongolian } \\
\text { oak }\end{array}$ & $314.2 \pm 4.5 b$ & $8.1 \pm 0.3 b$ & $0.7 \pm 0.1 b$ & $4.1 \pm 0.2 \mathrm{~b}$ & $21.8 \pm 0.6 b$ & $3.3 \pm 0.1 b$ & $38.7 \pm 1.9 b$ & $13.2 \pm 2.4 \mathrm{a}$ \\
\hline & Pine-oak & $367.9 \pm 5.0 \mathrm{~b}$ & $7.5 \pm 0.5 b$ & $1.0 \pm 0.4 \mathrm{a}$ & $3.8 \pm 0.3 \mathrm{bc}$ & $14.5 \pm 0.7 c$ & $2.7 \pm 0.1 \mathrm{c}$ & $49.34 \pm 3.3 b$ & $10.4 \pm 3.5 \mathrm{a}$ \\
\hline & $\begin{array}{l}\text { Chinese } \\
\text { pine }\end{array}$ & $413.6 \pm 5.2 \mathrm{a}$ & $5.9 \pm 0.2 \mathrm{a}$ & $1.1 \pm 0.5 \mathrm{a}$ & $3.3 \pm 0.1 \mathrm{c}$ & $9.3 \pm 0.3 \mathrm{~d}$ & $2.2 \pm 0.0 \mathrm{a}$ & $70.4 \pm 2.1 \mathrm{a}$ & $8.0 \pm 3.3 \mathrm{a}$ \\
\hline
\end{tabular}

Different letters in the same column represent a significant difference between leaf litters at the 0.05 level.

\subsection{Patterns of Leaf Litter Decomposition with Ambient N Deposition}

The patterns of leaf litter decomposition in the control plots reflect the natural process with ambient $\mathrm{N}$ deposition. At the end of the study period, there was no significant difference between the observed mass remaining $(41.1 \% \pm 0.2 \%)$ of litter mixture and the expected value 
$(38.3 \% \pm 0.3 \%)$, which was calculated as the sum of the individual litter's mass remaining and weighted by its proportion in the mixture. However, when considering the mass remaining of individual litter types decomposing alone or in the mixture, the interactions between the litter types became apparent (Figure 1). Mongolian oak litter decomposed at slower rates in the mixture than alone. In contrast, Chinese pine litter decomposed more slowly alone than in the mixture.
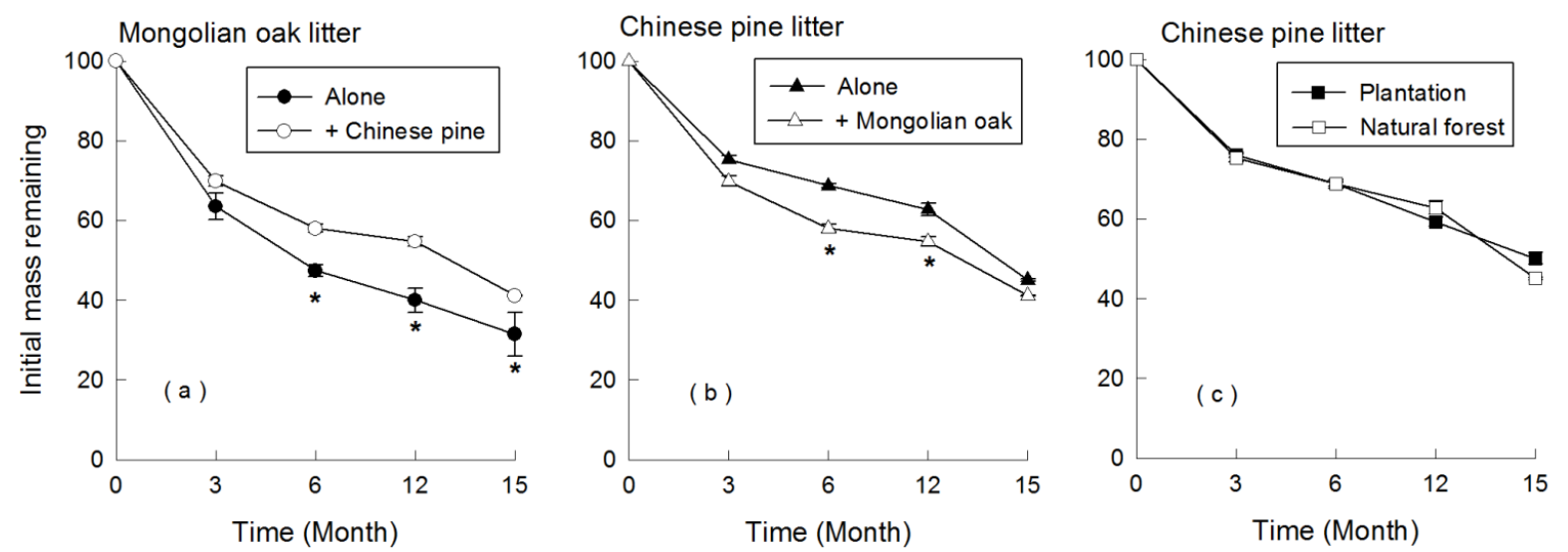

Figure 1. Percentages of remaining mass (\%) for each leaf litter. (a) Mongolian oak litter in the natural forest; (b) Chinese pine litter in the natural forest; and (c) Chinese pine litter in either plantation or natural forest. Error bars represent the standard errors of the means $(n=3)$. Asterisk indicates significant difference at $p<0.05$.

There was no significant difference between the plantation and natural forest in the remaining mass of Chinese pine litter at any sampling $(p>0.05)$. When averaged over the entire study period, Mongolian oak litter showed the most rapid decomposition rate $(k=0.84)$ when compared with the litter mixture $(k=0.59)$ and the Chinese pine litter in either plantation $(k=0.49)$ or natural forest $(k=0.52)$ (Table 4).

Table 4. Litter decomposition rate ( $k$-value) calculated using the first-order exponential decay model $\left(X_{t} / X_{0}=\mathrm{e}^{-k t}\right)$ and correlation coefficient $\left(R^{2}\right)$ for single-species litter and litter mixture under the four $\mathrm{N}$ addition treatments.

\begin{tabular}{cccccc}
\hline $\begin{array}{c}\text { Forest } \\
\text { Type }\end{array}$ & $\begin{array}{c}\text { Leaf } \\
\text { Litters }\end{array}$ & $\begin{array}{c}\text { Nitrogen } \\
\text { Treatment }\end{array}$ & $\boldsymbol{k}$-Value & $\boldsymbol{R}^{\mathbf{2}}$ & $\boldsymbol{p}$ \\
\hline \multirow{4}{*}{ Plantation } & Chinese & Control & $0.49 \pm 0.04 \mathrm{a}$ & 0.93 & $<0.001$ \\
& Low-N & $0.59 \pm 0.04 \mathrm{c}$ & 0.94 & $<0.001$ \\
& pine & Medium-N & $0.56 \pm 0.05 \mathrm{bc}$ & 0.92 & $<0.001$ \\
& & High-N & $0.52 \pm 0.04 \mathrm{ab}$ & 0.91 & $<0.001$ \\
\hline & & Control & $0.84 \pm 0.10 \mathrm{a}$ & 0.86 & $<0.001$ \\
& Mongolian & Low-N & $0.69 \pm 0.10 \mathrm{~b}$ & 0.79 & $<0.001$ \\
& oak & Medium-N & $0.65 \pm 0.10 \mathrm{~b}$ & 0.77 & $<0.001$ \\
& & High-N & $0.58 \pm 0.11 \mathrm{c}$ & 0.67 & $<0.001$ \\
\cline { 2 - 6 } Natural & & Control & $0.59 \pm 0.06 \mathrm{a}$ & 0.87 & $<0.001$ \\
forest & Pine-oak & Low-N & $0.60 \pm 0.07 \mathrm{a}$ & 0.86 & $<0.001$ \\
& & Medium-N & $0.62 \pm 0.07 \mathrm{a}$ & 0.86 & $<0.001$ \\
& & High-N & $0.57 \pm 0.08 \mathrm{a}$ & 0.81 & $<0.001$ \\
\cline { 2 - 6 } & & Control & $0.52 \pm 0.05 \mathrm{a}$ & 0.89 & $<0.001$ \\
& Chinese & Low-N & $0.51 \pm 0.05 \mathrm{ab}$ & 0.90 & $<0.001$ \\
& pine & Medium-N & $0.54 \pm 0.05 \mathrm{ab}$ & 0.91 & $<0.001$ \\
& & High-N & $0.60 \pm 0.05 \mathrm{~b}$ & 0.92 & $<0.001$ \\
\hline
\end{tabular}

$k$ values are means \pm SE $(n=3)$. Different lowercase letters indicate a significant difference $(p<0.05)$ among $\mathrm{N}$ addition treatments for each leaf litter. 


\subsection{Response of Leaf Litter Decomposition to N Addition}

Single-species litters and the litter mixture responded differently to $\mathrm{N}$ addition (Figure 2). In the plantation, the rate constants $(k)$ for the Chinese pine litter decreased in the order low-N (0.59) > medium-N (0.56) > high-N (0.52) > control (0.49) (Table 4). $\mathrm{N}$ addition raised the decomposition rate, and the differences between the control and the low- $\mathrm{N}$ as well as medium- $\mathrm{N}$ treatments were significant $(p<0.05$, Table 4). The effect of $\mathrm{N}$ addition on the decomposition rate varied depending on the length of exposure. The one-way ANOVA showed that there were significant differences in the rate constants between the control and high-N treatment after three and six months, and between the control and low-N treatment after 15 months $(p<0.05$, Figure 2).
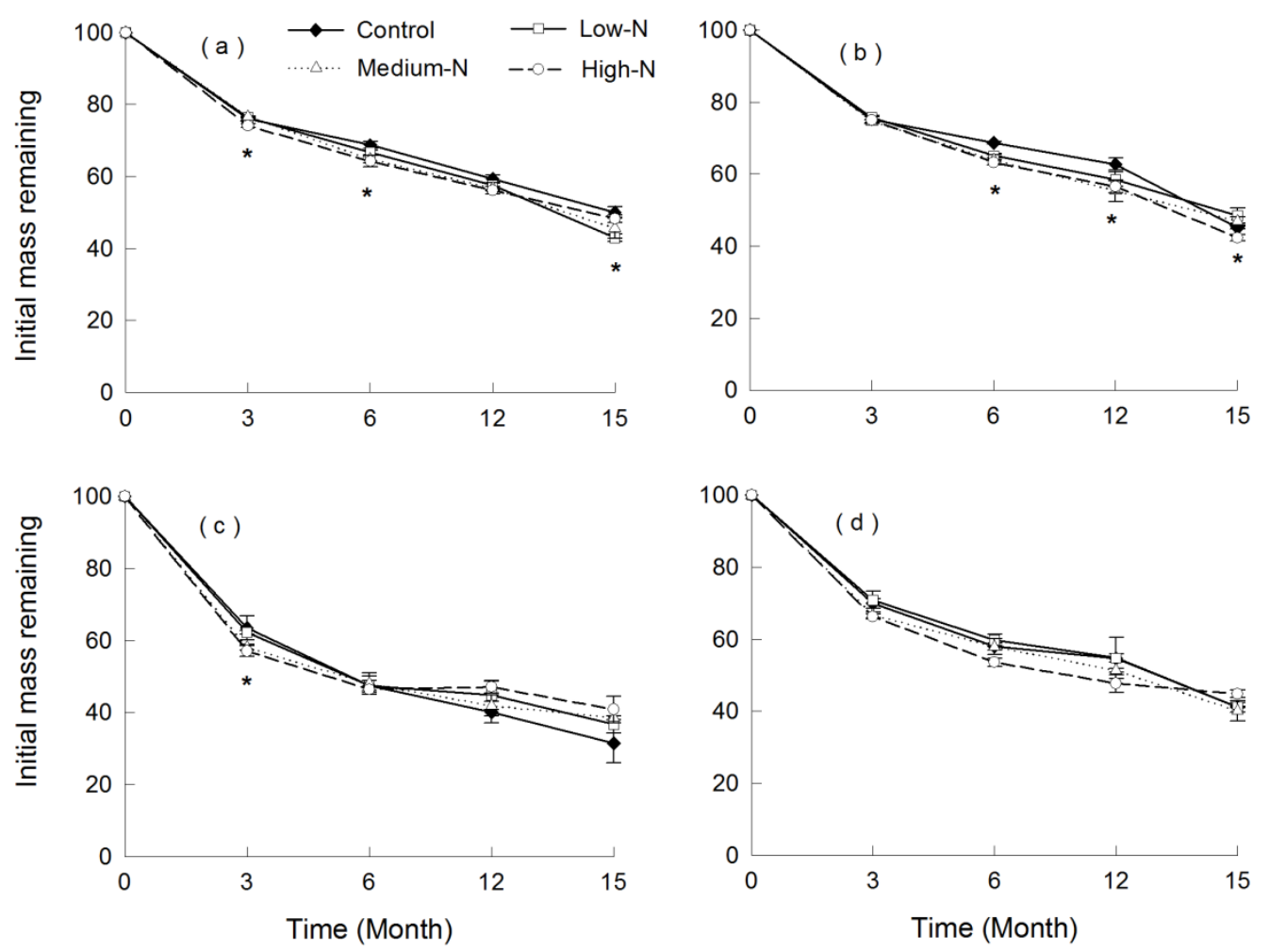

Figure 2. Percentagesof mass remaining (\%) in the different $\mathrm{N}$ addition treatments for each leaf litter. (a) Chinese pine litter in the plantation; (b) Chinese pine litter in the natural forest; (c) Mongolian oak litter in the natural forest; and (d) Pine-oak litter in the natural forest. Error bars represent the standard errors of the means $(n=3)$. Asterisk indicates significant difference at least between two treatments at $p<0.05$.

In the natural forest, the effect of $\mathrm{N}$ addition varied depending on the litter type, $\mathrm{N}$ addition treatment, and the length of exposure (Figure 2). A two-way ANOVA indicated that there was a significant difference in decomposition rates among $\mathrm{N}$ addition treatments over the entire study period for all litter types except for the litter mixture. Medium-N and high- $\mathrm{N}$ treatments increased the decomposition rate for the Chinese pine litter and the difference between the control and high-N treatment was significant $(p<0.05$, Table 4$)$. One-way ANOVA showed that there were significant differences among $\mathrm{N}$ addition treatments after six months for the Chinese pine litter. The rate constant $(k)$ of Mongolian oak litter decreased with $\mathrm{N}$ addition levels, and the differences among $\mathrm{N}$ addition treatments were significant $(p<0.05)$. One-way ANOVA showed that there was a significant difference in the decomposition rate between the control and high-N treatment after three months $(p<0.05$, Figure 1). No significant difference was found among the four $\mathrm{N}$ addition treatments in the remaining sampling dates (Figure 2). For the litter mixture, the rate constants $(k)$ decreased in 
the order medium- $\mathrm{N}(0.62)>$ low- $\mathrm{N}(0.60)>$ control $(0.59)>$ high- $\mathrm{N}(0.57)$. There were no significant differences in the decomposition rate among $\mathrm{N}$ addition treatments, although low- $\mathrm{N}$ and medium- $\mathrm{N}$ treatments accelerated the loss of mass.

\subsection{Nutrient Release}

$\mathrm{N}$ immobilization occurred at the early stage of litter mixture decomposition in the natural forest and Chinese pine litter in both the plantation and natural forest. No such $\mathrm{N}$ immobilization was found for the Mongolian oak litter in the control plot (Figure 3). In the plantation, $\mathrm{N}$ addition significantly increased $\mathrm{N}$ loss for the Chinese pine litter after three months $(p<0.05)$. In the natural forest, $\mathrm{N}$ loss occurred after six months and high- $\mathrm{N}$ treatment significantly stimulated $\mathrm{N}$ loss for the Chinese pine litter $(p<0.05)$. $\mathrm{N}$ immobilization occurred for $\mathrm{N}$ addition treatments at the early stage of decomposition of the Mongolian oak litter. When averaged over the entire study period, $\mathrm{N}$ addition significantly restrained $\mathrm{N}$ loss $(p<0.05)$. A similar trend was also found in the litter mixture.
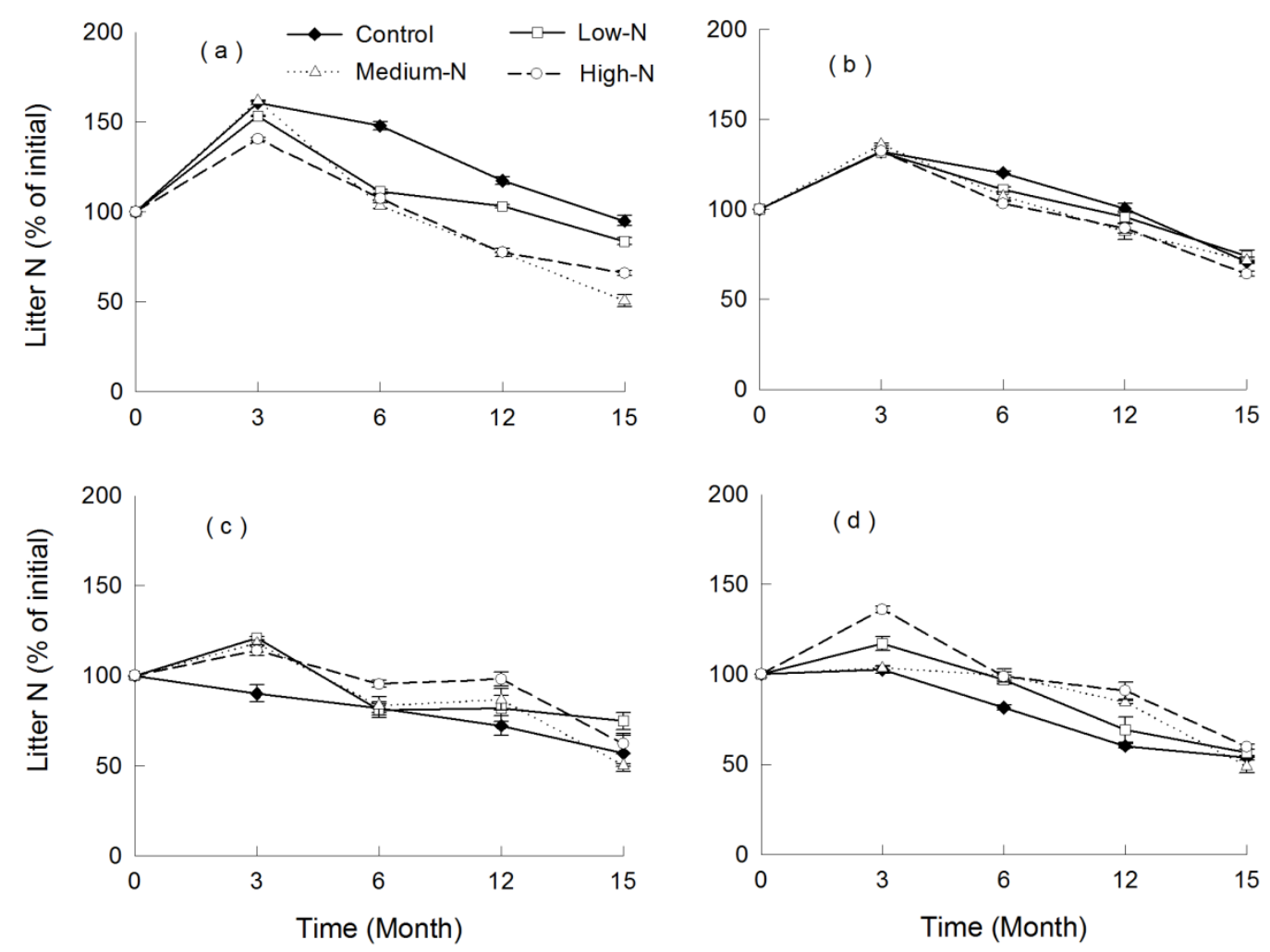

Figure 3. Mean litter nitrogen ( $\mathrm{N}, \%$ of initial) amount with standard error over time in the decomposition of each leaf litter under $\mathrm{N}$ addition treatments. (a) Chinese pine litter in the plantation; (b) Chinese pine litter in the natural forest; (c) Mongolian oak litter in the natural forest; and (d) Pine-oak litter in the natural forest.

For different leaf litters, $\mathrm{P}, \mathrm{K}$, and $\mathrm{Mg}$ immobilization did not occur throughout the decomposition process either in the control or in the $\mathrm{N}$ addition treatments (Figures 4-6). When averaged over the entire study period, $\mathrm{N}$ addition significantly increased $\mathrm{P}, \mathrm{K}$, and $\mathrm{Mg}$ losses for the Chinese pine litter in the plantation $(p<0.05)$. In the natural forest, a stimulating effect of $\mathrm{N}$ addition on the $\mathrm{P}, \mathrm{K}$, and $\mathrm{Mg}$ losses was also observed in the Chinese pine litter. For the Mongolian oak litter, the low- $\mathrm{N}$ and medium- $\mathrm{N}$ treatments suppressed $\mathrm{P}$ loss while the high-N treatment increased it. When averaged over the entire study period, $\mathrm{N}$ addition had no significant effect on $\mathrm{K}$ and $\mathrm{Mg}$ losses. For the litter mixture, only the high- $\mathrm{N}$ treatment had a significant stimulating effect on the $\mathrm{P}, \mathrm{K}$, and $\mathrm{Mg}$ losses. 

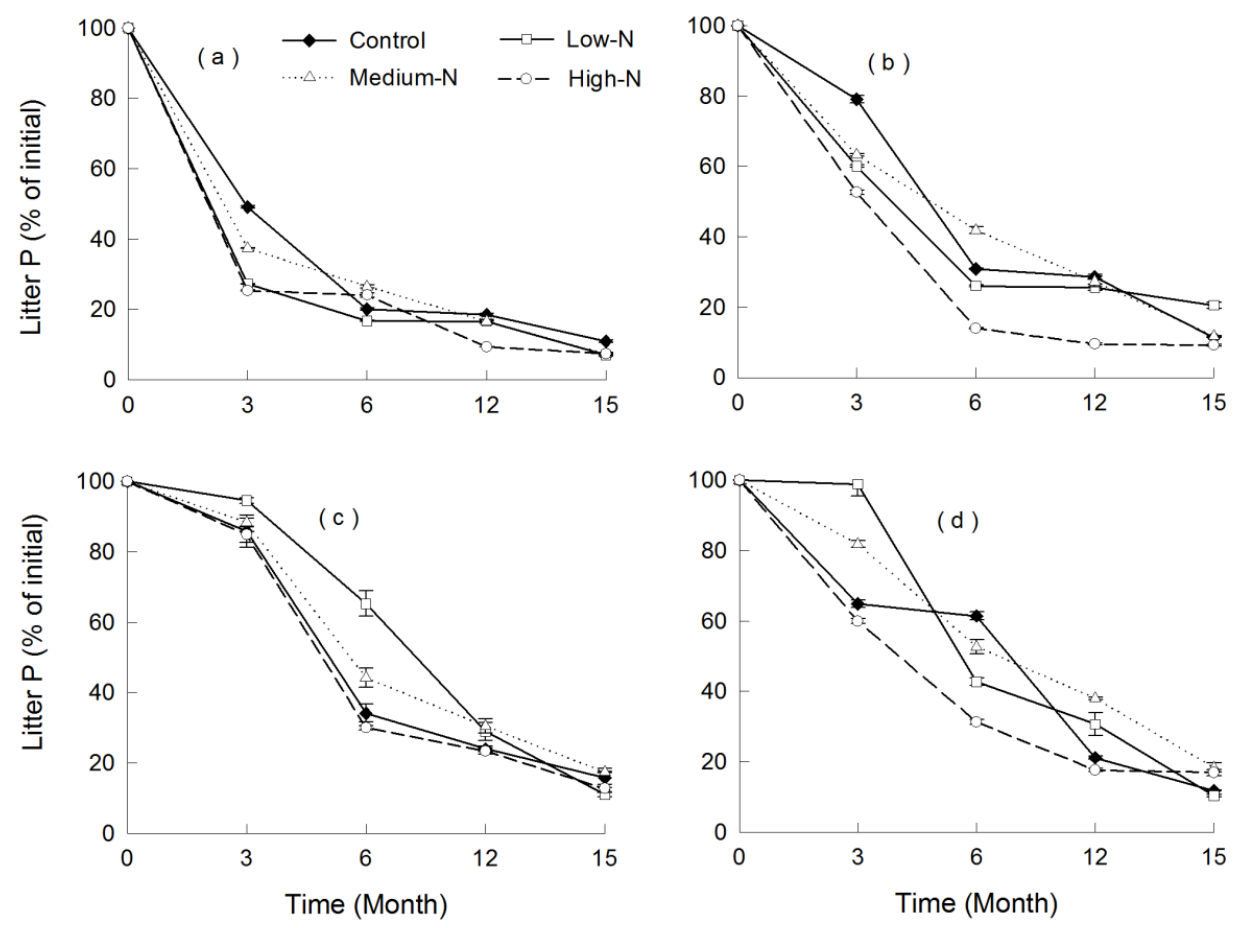

Figure 4. Mean litter phosphorus ( $\mathrm{P}, \%$ of initial) amount with standard error over time in the decomposition of each leaf litter under $\mathrm{N}$ addition treatments. (a) Chinese pine litter in the plantation; (b) Chinese pine litter in the natural forest; (c) Mongolian oak litter in the natural forest; and (d) Pine-oak litter in the natural forest.
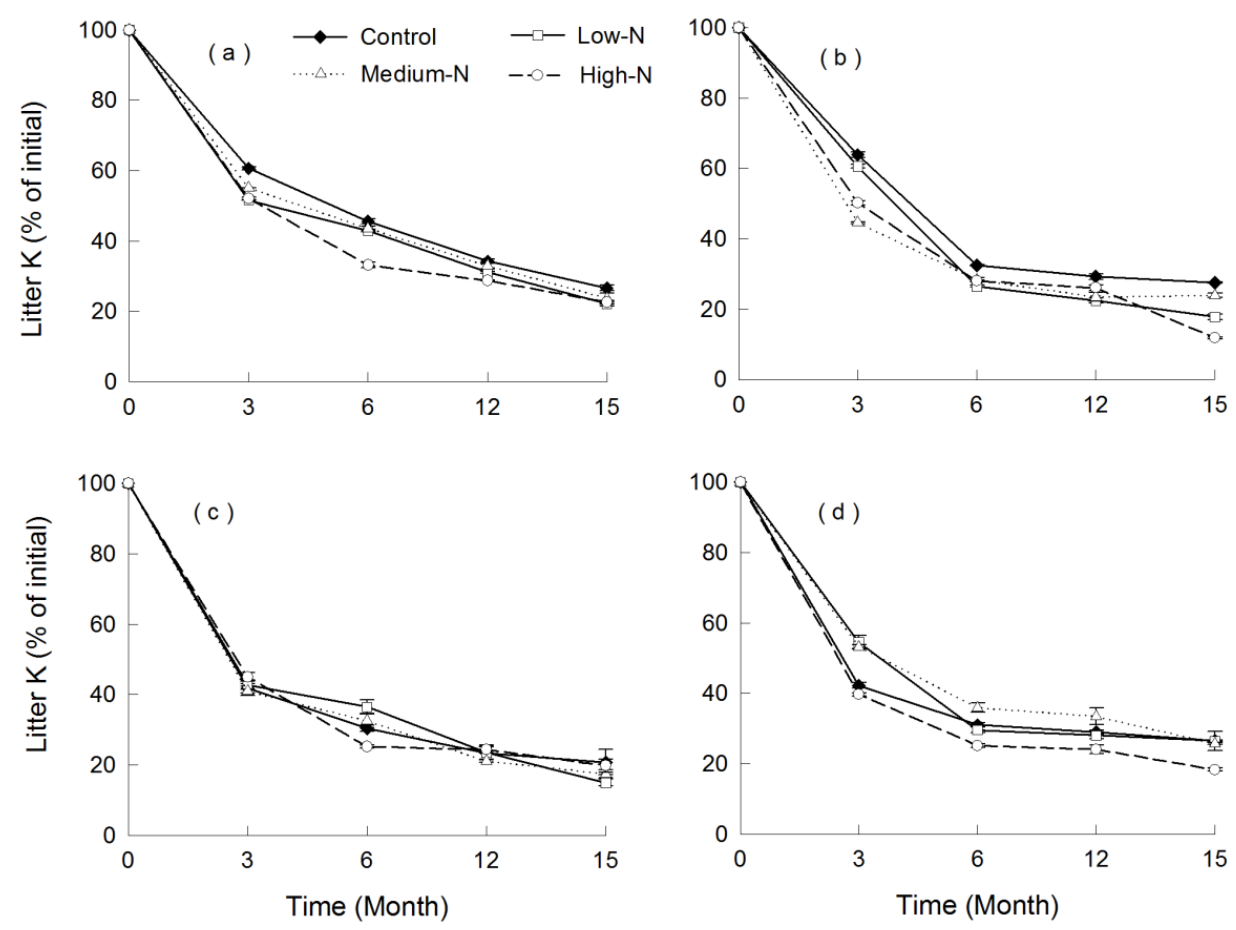

Figure 5. Mean litter potassium ( $\mathrm{K}, \%$ of initial) amount with standard error over time in the decomposition of each leaf litter under $\mathrm{N}$ addition treatments. (a) Chinese pine litter in the plantation; (b) Chinese pine litter in the natural forest; (c) Mongolian oak litter in the natural forest; and (d) Pine-oak litter in the natural forest. 

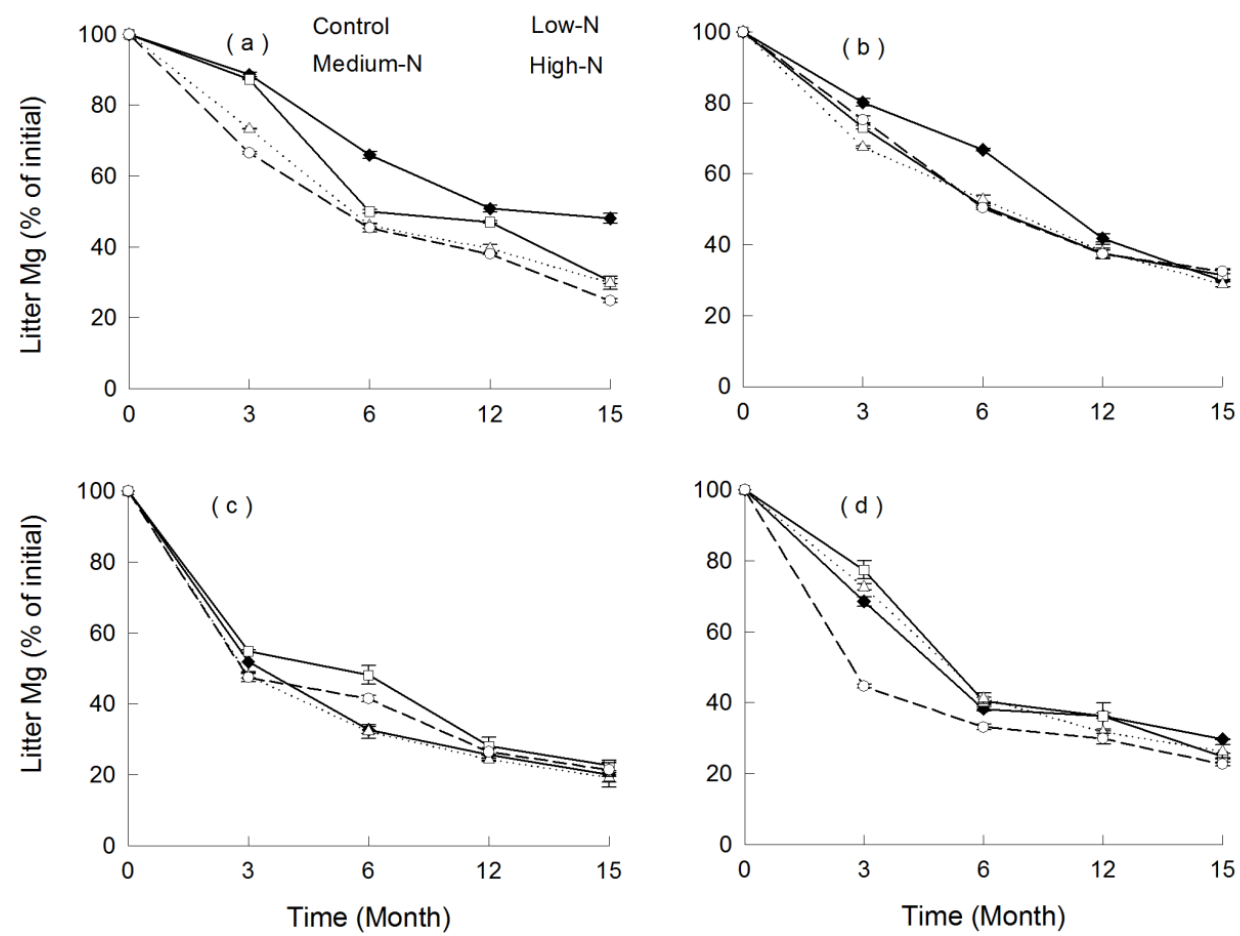

Figure 6. Mean litter magnesium ( $\mathrm{Mg}$, \% of initial) amount with standard error over time in the decomposition of each leaf litter under $\mathrm{N}$ addition treatments. (a) Chinese pine litter in the plantation; (b) Chinese pine litter in the natural forest; (c) Mongolian oak litter in the natural forest; and (d) Pine-oak litter in the natural forest.

\section{Discussion}

\subsection{Decomposition of Single-Species Litter}

The decomposition rates of single-species litters were in the order of (1) Mongolian oak in the natural forest; (2) Chinese pine in the natural forest; (3) Chinese pine in the plantation. These differences in the decomposition rates between the two stands could be mainly attributed to the species composition. Chinese pine growing with Mongolian oak in the natural forest may use site resources more efficiently in the decomposition process as they have substantially different characteristics such as foliar phenology, crown structure, and root morphology. In addition, the forest floor in the natural forest has a thicker organic layer and thus provides a superior micro-environment for the soil fauna and microbial communities, thereby hastening litter decomposition.

Numerous studies also suggest that the litter decomposition rate was more controlled by the substrate quality of the litter than the species composition in stands with similar climatic conditions [46-48]. Mongolian oak litter, with the lowest C: $\mathrm{N}$ ratio and highest initial $\mathrm{N}$ content, had a faster decomposition rate than the Chinese pine litter in either plantation or natural forest. This suggests that the $\mathrm{C}: \mathrm{N}$ ratio and initial $\mathrm{N}$ content could be the main drivers for litter decomposition. In comparison, initial $\mathrm{P}$ content seems a less relevant controlling factor in the present study, although some studies suggested that it is a good indicator of the decomposition rate [49]. Thus, Mongolian oak litter decomposed faster than Chinese pine litter, in spite of its much lower P concentration.

\subsection{Decomposition of Litter Mixture}

Despite the lack of difference between the observed and expected decomposition rate of the litter mixture as a whole, after separating the individual litter types in the mixture, a positive effect was found when the Chinese pine litter decomposed in the mixture with the Mongolian oak litter. 
Such a positive effect has also been reported by Lin et al. [37], when the litter of Mongolian pine (Pinus sylvestris var. mongolica) was mixed with two dominant understory species (Setaria viridis and Artemisia scoparia). In contrast, an opposite effect within the same mixture was found for the Mongolian oak litter. It has been reported that the nutrient-rich litter may induce a priming effect on the nutrient-poor litter in the mixture, facilitating faster decomposition of this litter without necessarily retarding the decomposition of the high quality litter [32]. Thus, the positive effect of the Mongolian oak litter on the Chinese pine litter decomposition in the mixture may be explained by microorganisms benefitting from the higher $\mathrm{N}$ concentrations of the Mongolian oak litter. Based on the low $\mathrm{N}$ concentration and high $\mathrm{C}: \mathrm{N}$ ratio of the Chinese pine litter $(\mathrm{C}: \mathrm{N}=70.4)$, decomposing Chinese pine litter did accumulate $\mathrm{N}$. In the case of the litter mixture, this $\mathrm{N}$ may have been transferred from the Mongolian oak litter, which had experienced net losses after 12 months.

Besides nutrient transfer among litter types, there were some other mechanisms that may have contributed to explain the differences in the decomposition of the litter mixture. For instance, heterogeneity in lignin concentration in the mixture may enhance the decomposition of the Chinese pine litter, as was reported previously for the litter mixture with heterogeneity in recalcitrant compounds [50]. Most importantly, individual leaves of mixture litters are typically of different sizes, shapes, and surface structures. Such differences influence the microclimatic conditions for the soil biota and thus affect the decomposition.

Our results also suggest that the litter mixing effect varies depending on the length of exposure. For instance, a positive effect on the Chinese pine litter was only found after six and 12 months, whereas there was no significant difference in the remaining mass between the litter mixture and the Chinese pine litter alone at the end of the study period. A comprehensive explanation is somewhat constrained by our experimental design, but we may speculate that the biotic degradation of organic compounds could be responsible for the time dependence of the litter mixing effect [51]. During the first six and 12 months mainly soluble compounds, cellulose, and amino acids are degraded, which contributed to the significant difference between the litter mixture and the Chinese pine litter in the remaining mass [46]. However, the lignin concentration becomes more important and controls the later stage of litter decomposition, which caused the litter mixing effect to disappear.

\subsection{Effect of $N$ Addition on Litter Decomposition}

The exogenous $\mathrm{N}$ addition significantly stimulated the decomposition of Chinese pine litter in the plantation. This may be attributed to the alleviation of $\mathrm{N}$ limitations on soil microbes with the increasing availability of external $\mathrm{N}$ for soil microorganisms [45]. The plantation was subject to selective logging in the 1980s. The disturbance was generally caused by the harvesting of dominant trees and the understory. This harvesting practice not only removed nutrients, but also organic matter that is an essential substrate for microbial activity, resulting in high $\mathrm{N}$ leaching losses. For instance, the mean soil organic carbon was $22.7 \mathrm{~g} \cdot \mathrm{kg}^{-1}$ in the plantation, which was significantly lower than the corresponding $44.9 \mathrm{~g} \cdot \mathrm{kg}^{-1}$ in the natural forest. As a result, the site productivity and $\mathrm{N}$ availability is low as had been reported previously for the temperate forest $[13,30,37]$. It has also been suggested that $\mathrm{N}$ addition to $\mathrm{N}$-limited forests will initially stimulate microbial activity, but eventually results in a carbon-limited state when microbial demand for $\mathrm{N}$ has been satisfied [6]. The long-term effect of $\mathrm{N}$ addition on litter decomposition in the plantation thus needs to be further investigated.

The results of nitrogen addition in the natural forest showed a different trend. No positive effects and even some negative effects of $\mathrm{N}$ addition on the litter decomposition were found for different litter types. Our results are in agreement with the conclusion made by Fog [52] that $\mathrm{N}$ addition generally has either no effect or a negative effect on the litter decomposition in the long term. The reasons for our results may be explained as follows. First, a stimulatory effect of high-N treatment on the Chinese pine litter decomposition could be attributed to a decrease in the substrate $\mathrm{C}: \mathrm{N}$ ratio. However, an opposite effect was found for the Mongolian oak litter decomposition. The stimulating 
effect of $\mathrm{N}$ addition on the Chinese pine litter may offset the suppressive effect on the Mongolian oak litter, resulting in a neutral effect on the litter mixture.

Second, the $\mathrm{N}$ addition effect is likely to be correlated with the stages of litter decomposition. As reported, there are two distinct stages of litter decomposition. The early stage is characterized by a rapid release of labile compounds, such as sugar, protein, and amino acids. Several studies have shown that $\mathrm{N}$ addition accelerates this stage of litter decomposition $[45,47,53]$. However, at later stages, litter decomposition is mainly controlled by lignin dynamics. It is likely that higher $\mathrm{N}$ addition inhibits the lignin decomposition either by inhibiting the production of lignolytic enzymes or by reacting with the breakdown products of lignin degradation to form more recalcitrant materials, hence decreasing the litter decomposition rate [33].Third, the demand for $\mathrm{N}$ by decomposers may be low relative to supply because of the decreased carbon supply from litter decomposition to the decomposers [54]. An experiment in the same area has shown that $\mathrm{N}$ addition significantly decreased the enzyme activities of peroxidase and polyphenol oxidase, resulting in a decline in the amount of soil organic carbon, thus inhibiting the decomposers growth [55].

\section{Conclusions}

Single-species litter decomposition was mainly controlled by litter quality such as initial $\mathrm{N}$ content and the $\mathrm{C}: \mathrm{N}$ ratio. Chinese pine litter decomposed faster when mixed with the Mongolian oak litter. This suggests that increases in litter decomposition can be expected in a mixed forest of Chinese pine and Mongolian oak, thus enhancing the soil fertility of the natural forest. $\mathrm{N}$ addition significantly stimulated the decomposition of Chinese pine litter in the plantation. No positive effects and even some negative effects of $\mathrm{N}$ addition on the litter decomposition were found in the decomposed litters of the natural forest. These results suggest that the stimulatory effect of $\mathrm{N}$ addition on the decomposition of Chinese pine litter in the plantation accelerates nutrient returns to the soil, thus increasing soil fertility. However, $\mathrm{N}$ addition also increases the potential of $\mathrm{CO}_{2}$ emissions to the atmosphere for the Chinese pine litter in the plantation. The negative effects of $\mathrm{N}$ addition on the litter decomposition in the natural forest may lead to soil degradation in the long term. $\mathrm{N}$ addition may also increase the soil $\mathrm{C}$ storage through suppressing the litter decomposition and conserving more stable organic matter in the soil in the natural forest. Meanwhile, with the expected increase in human activities in the coming decades, $\mathrm{N}$ deposition is likely to increase rapidly in the region where this study was undertaken. Thus, further investigations are required to characterize the effects of long-term high-level $\mathrm{N}$ deposition on the litter decomposition in the studied forest ecosystems.

Acknowledgments: We thank Na Wang for help with lab and field measurements. This study was financially supported by the National Basic Research Program of China (973 Program; 2011CB403203) and the State Key Program of National Natural Science Foundation of China (41330530). The funders had a role in study design, data collection and analysis, decision to publish, and preparation of the manuscript.

Author Contributions: Jinsong Wang conducted this research and wrote this manuscript. Xiuhai Zhao and Chunyu Zhang designed this experiment and provided strategic direction for the development of the manuscript. Wensheng Bu, Bo Zhao, Juan Fan and Klaus V. Gadow contributed to data analysis and development of the manuscript. All the authors read and approved the final version of the manuscript.

Conflicts of Interest: The authors declare no conflict of interest.

\section{References}

1. Galloway, J.N.; Townsend, A.R.; Erisman, J.W.; Bekunda, M.; Cai, Z.; Freney, J.R.; Martinelli, L.A.; Seitzinger, S.P.; Sutton, M.A. Transformation of the nitrogen cycle: Recent trends, questions and potential solutions. Science 2008, 320, 889-892. [CrossRef] [PubMed]

2. Vitousek, P.M.; Aber, J.D.; Howarth, R.W.; Likens, G.E.; Matson, P.A.; Schindler, D.W.; Schlesinger, W.H.; Tilman, D.G. Human alteration of the global nitrogen cycle: Sources and consequences. Ecol. Appl. 1997, 7, 737-750. [CrossRef]

3. Reay, D.S.; Dentener, F.; Smith, P.; Grace, J.; Feely, R.A. Global nitrogen deposition and carbon sinks. Nat. Geosci. 2008, 1, 430-437. [CrossRef] 
4. Galloway, J.N.; Cowling, E.B. Reactive nitrogen and the world: 200 years of change. Ambio J. Hum. Environ. 2002, 31, 64-71. [CrossRef]

5. Zheng, X.H.; Fu, C.B.; Xu, X.K.; Yan, X.D.; Huang, Y.; Han, S.H.; Hu, F.; Chen, G.X. The Asian nitrogen cycle case study. Ambio A Journal of the Human Environment 2002, 31, 79-87. [CrossRef]

6. Aber, J.D.; Goodale, C.L.; Ollinger, S.V.; Smith, M.L.; Magill, A.H.; Martin, M.E.; Hallett, R.A.; Stoddard, J.L. Is nitrogen deposition altering the nitrogen status of northeastern forests? Bioscience 2003, 53, 375-389. [CrossRef]

7. Vivanco, L.; Austin, A.T. Intrinsic effects of species on leaf litter and root decomposition: A comparison of temperate grasses from North and South America. Oecologia 2006, 150, 97-107. [CrossRef] [PubMed]

8. Buchmann, N. Biotic and abiotic factors controlling soil respiration rates in Picea abies stands. Soil Biol. Biochem. 2000, 32, 1625-1635. [CrossRef]

9. Fenn, M.E.; Baron, J.S.; Allen, E.B.; Rueth, H.M.; Nydick, K.R.; Geiser, L.; Bowman, W.D.; Sickman, J.O.; Meixner, T.; Johnson, D.W.; et al. Ecological effects of nitrogen deposition in the western United States. Bioscience 2003, 53, 404-420. [CrossRef]

10. Zhou, G.Y.; Guan, L.L.; Wei, X.H.; Tang, X.L.; Liu, S.G.; Liu, J.X.; Zhang, D.Q.; Yan, J.H. Factors influencing leaf litter decomposition: An intersite decomposition experiment across China. Plant Soil 2008, 311, 61-72. [CrossRef]

11. Swift, M.J.; Heal, O.W.; Anderson, J.M. Decomposition in Terrestrial Ecosystems; Blackwell: Oxford, UK, 1979.

12. Rustad, L.E.; Campbell, J.L.; Marion, G.M.; Norby, R.J.; Mitchell, M.J.; Hartley, A.E.; Cornelissen, J.H.C.; Gurevitch, J. A meta-analysis of the response of soil respiration, net nitrogen mineralization, and aboveground plant growth to experimental ecosystem warming. Oecologia 2001, 126, 543-562.

13. Hobbie, S.E. Nitrogen effects on decomposition: A five-year experiment in eight temperate sites. Ecology 2008, 89, 2633-2644. [CrossRef] [PubMed]

14. Chen, H.; Dong, S.F.; Liu, L.; Ma, C.; Zhang, T.; Zhu, X.M.; Mo, J.M. Effects of experimental nitrogen and phosphorus addition on litter decomposition in an old-growth tropical forest. PLoS ONE 2013, 8, e84101. [CrossRef] [PubMed]

15. Tu, L.H.; Hu, H.L.; Chen, G.; Peng, Y.; Xiao, Y.L.; Hu, T.X.; Zhang, J.; Li, X.W.; Liu, L.; Tang, Y. Nitrogen addition significantly affects forest litter decomposition under high levels of ambient nitrogen deposition. PLoS ONE 2014, 9, e88752. [CrossRef] [PubMed]

16. Prescott, C.E. Does nitrogen availability control rates of litter decomposition in forests? Plant Soil 1995, 168-169, 83-88. [CrossRef]

17. Hobbie, S.E. Interactions between litter lignin and soil $\mathrm{N}$ availability during leaf litter decomposition in a Hawaiian montane forest. Ecosystems 2000, 3, 484-494. [CrossRef]

18. Allison, S.D.; LeBauer, D.S.; Ofrecio, M.R.; Reyes, R.; Ta, A.M.; Tran, T. Low levels of nitrogen addition stimulate decomposition by boreal forest fungi. Soil Biol. Biochem. 2009, 41, 293-302. [CrossRef]

19. Jiang, X.Y.; Cao, L.X.; Zhang, R.D.; Yan, L.J.; Mao, Y.; Yang, Y.W. Effects of nitrogen addition and litter properties on litter decomposition and enzyme activities of individual fungi. Appl. Soil Ecol. 2014, 80, 108-115. [CrossRef]

20. Knorr, M.; Frey, S.D.; Curtis, P.S. Nitrogen additions and litter decomposition: A meta-analysis. Ecology 2005, 86, 3252-3257. [CrossRef]

21. Laganière, J.; Paré, D.; Bradley, R.L. How does a tree species influence litter decomposition? Separating the relative contribution of litter quality, litter mixing, and forest floor conditions. Can. J. For. Res. 2010, 40, 465-475. [CrossRef]

22. Prescott, C.E.; Zabek, L.M.; Staley, C.L.; Kabzems, R. Decomposition of broadleaf and needle litter in forests of British Columbia: Influences of litter type, forest type, and litter mixtures. Can. J. For. Res. 2000, 30, 1742-1750. [CrossRef]

23. Berger, T.W.; Berger, P. Does mixing of beech (Fagus sylvatica) and spruce (Picea abies) litter hasten decomposition? Plant Soil 2014, 377, 217-234. [CrossRef] [PubMed]

24. Scherer-Lorenzen, M. Functional diversity affects decomposition processes in experimental grasslands. Funct. Ecol. 2008, 22, 547-555. [CrossRef]

25. Gartner, T.B.; Cardon, Z.G. Decomposition dynamics in mixed-species leaf litter. Oikos 2004, 104, $230-246$. [CrossRef] 
26. Quested, H.M.; Cornelissen, J.H.C.; Press, M.C.; Callaghan, T.V.; Aerts, R.; Trosien, F.; Riemann, P.; Gwynn-Jones, D.; Kondratchuk, A.; Jonasson, S.E. Decomposition of sub-arctic plants with nitrogen economics: A functional role for hemi-parasites. Ecology 2003, 84, 3209-3221. [CrossRef]

27. Hättenschwiler, S.; Tiunov, A.V.; Scheu, S. Biodiversity and litter decomposition in terrestrial ecosystems. Annu. Rev. Ecol. Evol. Syst. 2005, 36, 191-218. [CrossRef]

28. Wardle, D.A.; Bardgett, R.D.; Walker, L.R.; Bonner, K.I. Among- and within-species variation in plant litter decomposition in contrasting long-term chronosequences. Funct. Ecol. 2009, 23, 442-453. [CrossRef]

29. Moore, T.R.; Trofymow, J.A.; Prescott, C.E.; Titus, B.D. Nature and nurture in the dynamics of C, N and P during litter decomposition in Canadian forest. Plant Soil 2011, 339, 163-175. [CrossRef]

30. Zhao, J.L.; Kang, F.F.; Wang, L.X.; Yu, X.W.; Zhao, W.H.; Song, X.S.; Zhang, Y.L.; Chen, F.; Sun, Y.; He, T.F.; et al. Patterns of biomass and carbon distribution across a chronosequence of Chinese pine (Pinus tabulaeformis) forests. PLoS ONE 2014, 9, e94966. [CrossRef] [PubMed]

31. Guo, H.; Wang, B.; Ma, X.Q.; Zhao, G.D.; Li, S.N. Evaluation of ecosystem services of Chinese pine forests in China. Sci. China C Life Sci. 2008, 51, 662-670. [CrossRef] [PubMed]

32. Montané, F.; Romanyà, J.; Rovira, P.; Casals, P. Mixtures with grass litter may hasten shrub litter decomposition after shrub encroachment into mountain grasslands. Plant Soil 2013, 368, 459-469. [CrossRef]

33. Liu, P.; Sun, O.J.; Huang, J.H.; Li, L.H.; Han, X.G. Nonadditive effects of litter mixtures on decomposition and correlation with initial litter $\mathrm{N}$ and $\mathrm{P}$ concentrations in grassland plant species of northern China. Biol. Fertil. Soils 2007, 44, 211-216. [CrossRef]

34. Smith, V.C.; Bradford, M.A. Do non-additive effects on decomposition in litter-mix experiments result from differences in resource quality between litter? Oikos 2003, 102, 235-243. [CrossRef]

35. Liu, P.; Huang, J.H.; Sun, O.J.X.; Han, X.G. Litter decomposition and nutrient release as affected by soil nitrogen availability and litter quality in a semiarid grassland ecosystem. Oecologia 2010, 162, 771-780. [CrossRef] [PubMed]

36. Vivanco, L.; Austin, A.T. Nitrogen addition stimulates forest litter decomposition and disrupts species interactions in Patagonia, Argentina. Glob. Chang. Biol. 2011, 17, 1963-1974. [CrossRef]

37. Lin, G.G.; Mao, R.; Zhao, L.; Zeng, D.H. Litter decomposition of a pine plantation is affected by species evenness and soil nitrogen availability. Plant Soil 2013, 373, 649-657. [CrossRef]

38. Li, H.S.; Wang, J.S.; Liu, X.; Jiang, S.S.; Zhang, C.Y.; Zhao, X.H. Effects and its sustained effect of simulated nitrogen deposition on soil respiration in Pinus tabulaeformis forests in the Taiyue Mountain, China. Acta Sci.Circums. 2014, 34, 238-249, (In Chinese).

39. Pruden, G.; Powlson, D.S.; Jenkinson, D.S. The measurement of ${ }^{15} \mathrm{~N}$ in soil and plant material. Fertil. Res. 1985, 6, 205-218. [CrossRef]

40. Nanjing Agricultural University. Soil and Agricultural Chemistry Analysis; China Agriculture Press: Beijing, China, 1988. (In Chinese)

41. Kalembasa, S.J.; Jenkinson, D.S. A comparative study of titrimetric and gravimetric methods for the determination of organic carbon in soil. J. Sci. Food Agric. 1973, 24, 1085-1090. [CrossRef]

42. Herrmann, S.; Kahl, T.; Bauhus, J. Decomposition dynamics of coarse woody debris of three important central European tree species. For. Ecosystems 2015, 2, 1-14. [CrossRef]

43. Olson, J.S. Energy storage and the balance of producers and decomposition in ecological system. Ecology 1963, 44, 322-331. [CrossRef]

44. Brandt, L.A.; King, J.Y.; Hobbie, S.E.; Milchunas, D.G.; Sinsabaugh, R.L. The role of photodegradation in surface litter decomposition across a grassland ecosystem precipitation gradient. Ecosystems 2010, 13, 765-781. [CrossRef]

45. Lv, Y.N.; Wang, C.Y.; Wang, F.Y.; Zhao, G.Y.; Pu, G.Z.; Ma, X.; Tian, X.J. Effects of nitrogen addition on litter decomposition, soil microbial biomass, and enzyme activities between leguminous and non-leguminous forests. Ecol. Res. 2013, 28, 793-800. [CrossRef]

46. Singh, K.P.; Singh, P.K.; Tripathi, S.K. Litterfall, litter decomposition and nutrient release patterns in four native tree species raised on coal mine spoilat Singrauli, India. Biol. Fertil. Soils 1999, 29, 371-378. [CrossRef]

47. Song, C.C.; Liu, D.Y.; Yang, G.S.; Song, Y.Y.; Mao, R. Effect of nitrogen addition on decomposition of Calamagrostis angustifolia litters from freshwater marshes of Northeast China. Ecol. Eng. 2011, 37, 1578-1582. [CrossRef] 
48. Zhang, W.D.; Wang, S.L. Effects of $\mathrm{NH}_{4}{ }^{+}$and $\mathrm{NO}_{3}{ }^{-}$on litter and soil organic carbon decomposition in a Chinese fir plantation forest in South China. Soil Biol. Biochem. 2012, 47, 116-122. [CrossRef]

49. Li, L.J.; Zeng, D.H.; Yu, Z.Y.; Fan, Z.P.; Yang, D.; Liu, Y.X. Impact of litter quality and soil nutrient availability on leaf decomposition rate in a semi-arid grassland of Northeast China. J. Arid Environ. 2011, 75, 787-792. [CrossRef]

50. Perez Harguindeguy, N.; Blundo, C.M.; Gurvich, D.E.; Díaz, S.; Cuevas, E. More than the sum of its parts? Assessing litter heterogeneity effects on the decomposition of litter mixtures through leaf chemistry. Plant Soil 2008, 303, 151-159. [CrossRef]

51. Blair, J.M.; Parmalee, W.; Baere, M.H. Decay rates, nitrogen fluxes, and decomposer communities of single- and mixed- species foliar litter. Ecology 1990, 71, 1976-1985. [CrossRef]

52. Fog, K. The effect of added nitrogen on the rate of decomposition of organic matter. Biol. Rev. 1988, 63, 433-462. [CrossRef]

53. Mo, J.M.; Brown, S.; Xue, J.H.; Fang, Y.T.; Li, Z.A. Response of litter decomposition to simulated nitrogen deposition in disturbed, rehabilitated and mature forests in subtropical China. Plant Soil 2006, 285, 135-151. [CrossRef]

54. Adersson, M.; Kjoller, A.; Struwe, S. Microbial enzyme activities in leaf litter, humus and mineral soil layers of European forests. Soil Biol. Biochem. 2004, 36, 1527-1537. [CrossRef]

55. Liu, X.; Wang, J.S.; Zhao, X.H. Effects of simulated nitrogen deposition on the soil enzyme activities in a Pinus tabulaeformis forest at the Taiyue Mountain. Acta Ecol. Sin. 2015, 35, 4613-4624, (In Chinese).

(C) 2015 by the authors; licensee MDPI, Basel, Switzerland. This article is an open access article distributed under the terms and conditions of the Creative Commons by Attribution (CC-BY) license (http://creativecommons.org/licenses/by/4.0/). 